\title{
Analisis Pengaruh Datum Vertikal Akibat Perubahan Undang-Undang Nomor 32 Tahun 2004 Menjadi Undang-Undang Nomor 23 Tahun 2014 Terhadap Penetapan Batas Wilayah Laut
}

\author{
(Analysis of The Effect of Vertical Datum on The Amendment Law Number 32 of 2004 Become Law \\ Number 23 of 2014 on Sea Boundary)
}

Luhur Moekti Prayogo1, Sumaryo Joyosumarto²

\begin{abstract}
1Program Studi Ilmu Kelautan, Fakultas Perikanan dan Kelautan, Universitas PGRI Ronggolawe, Tuban, Indonesia
2Departemen Teknik Geodesi, Fakultas Teknik, Universitas Gadjah Mada, Yogyakarta, Indonesia
\end{abstract}

Penulis Korespondensi: Sumaryo Joyosumarto | Email: sumaryo@ugm.ac.id

Diterima (Received): 21/07/2021 Direvisi (Revised): 02/11/2021 Diterima untuk Publikasi (Accepted): 16/11/2021

\begin{abstract}
ABSTRAK
Di Indonesia, aturan mengenai batas wilayah laut diatur oleh Undang-Undang Nomor 32 Tahun 2004 dan kemudian digantikan dengan Undang-Undang Nomor 23 Tahun 2014 karena sudah tidak relevan dengan kebijakan dan penyelenggaraan pemerintah. Perbedaan kedua undang-undang tersebut salah satunya mengatur mengenai garis pantai yang digunakan sebagai acuan penarikan garis batas. Pada undang-undang yang lama, acuan penarikan garis batas berdasarkan air surut terendah (Low Water), sedangkan pada aturan perundang-undangan yang baru mengacu pada batas pasang air laut tertinggi (High Water). Penelitian ini bertujuan untuk mengetahui pengaruh datum vertikal sebagai garis dasar dalam penegasan batas wilayah laut akibat perubahan UndangUndang. Penelitian ini dibatasi dengan studi literatur pada dokumen diantaranya Undang-Undang dan dokumen terkait. Analisis spasial dilakukan untuk mengetahui pengaruh kelerengan terhadap pergeseran garis dasar di lapangan dan di peta. Dari kajian dan analisis spasial yang dilakukan dapat disimpulkan bahwa pergeseran LW ke HW dengan beberapa pendekatan kemiringan wilayah menunjukkan pergeseran-pergeseran tersebut hampir tidak terlihat atau bisa dikatakan tidak signifikan untuk dasar mengukur limit batas maritim. Penentuan garis dasar LW ke HW akan mempengaruhi luas pengelolaan wilayah laut, garis dasar dan titik dasar. Semakin rendah garis dasar maka semakin sempit wilayah pengelolaan laut. Sebaliknya, semakin tinggi garis dasar maka semakin luas wilayah pengelolaan laut. Letak garis dasar LW dan HW akan berdampak pada lokasi SDA khususnya pada wilayah yang berdampingan dekat dengan wilayah lain. Luas wilayah mempengaruhi besaran DBH pada suatu wilayah yang ditentukan dari garis dasar.
\end{abstract}

Kata Kunci: Undang-Undang No.32 Tahun 2004, Undang-Undang No. 23 Tahun 2014, Garis Pangkal, Low and High Water, Batas Laut

\begin{abstract}
In Indonesia, the rules regarding maritime boundaries are regulated by Law Number 32 of 2004 and then replaced by Law Number 23 of 2014 because it is no longer relevant to current government policies and administration. One of the differences between the two laws is that it regulates the coastline used as a reference for drawing the boundary line. In the old law, the reference for drawing the boundary line was based on the lowest tide, while in the new law, it referred to the highest tide limit. This study aims to determine the effect of the vertical datum as a baseline in the affirmation of maritime boundaries. This research is limited to the literature study on documents including laws and related documents. Spatial analysis was conducted to determine the slope effect on baseline shifts in the field and on the map. From the study and spatial analysis conducted, it can be concluded that the LW to HW shift with several regional slope approaches shows that these shifts are almost invisible or can be said to be insignificant for the basis of measuring maritime boundary limits. Determination of the baseline LW and HW will affect the management area of the sea area, baseline, and base point. The lower the baseline, the narrower the marine management area. On the other hand, the higher the baseline, the wider the marine management area. The location of the LW and HW baselines will impact the location of natural resources, especially in areas adjacent to other areas. The size of the area affects the amount of DBH in an area which is determined from the baseline.
\end{abstract}

Keywords: Law No. 32 of 2004, Law No. 23 of 2014, Baseline, Low and High Water, Sea Boundary

(C) Author(s) 2021. This is an open access article under the Creative Commons Attribution-ShareAlike 4.0 International License (CC BY-SA 4.0). 


\section{Pendahuluan}

Wilayah Indonesia merupakan negara maritim karena terdiri dari beberapa pulau serta mayoritas wilayahnya adalah lautan (Adikara \& Munandar, 2021). Sebagai negara yang berbatasan langsung, tak jarang Indonesia dihinggapi konflik perbatasan (Lamionda, 2020). Demi menghindari konflik, negara-negara pantai membuat perjanjian baik dalam bentuk regional, bilateral maupun multilateral (Karlina, 2020). Batas daerah merupakan pemisah wilayah penyelenggaraan kewenangan suatu daerah dengan daerah lain baik yang berada di darat maupun di laut yang tidak menentukan kedaulatan baru (Peraturan Menteri Dalam Negeri, 2012a). Kapahese dkk (2021) menyatakan bahwa wilayah laut adalah laut beserta tanah yang ada di bawahnya dimana tanah di bawah laut adalah dasar laut. Pada batas daerah di laut, penentuan garis batas antar wilayah merupakan kumpulan titik-titik koordinat yang diukur dari garis pantai. Indonesia dengan 34 provinsi dibutuhkan batas daerah yang tegas dan jelas untuk mengelola sumber daya dan kewenangan daerah setiap provinsi. Abidin (2001); Arddinatarta dkk (2016) menyatakan bahwa tingginya nilai batas pengelolaan wilayah laut baik pada daerah bersangkutan maupun daerah perbatasan menjadi nilai strategis sehingga penegasan batas laut menjadi penting. Batas laut daerah dibutuhkan untuk mengoptimalkan pengelolaan sumber daya alam yang ada di setiap daerah serta menghindari konflik terkait keberadaan sumber daya di masa mendatang (Prayogi, 2016).

Di Indonesia, aturan mengenai batas daerah diatur oleh Undang-Undang (UU) Nomor 32 Tahun 2004 dan kemudian digantikan dengan Undang-Undang (UU) Nomor 23 Tahun 2014 karena sudah tidak relevan dengan kebijakan dan penyelenggaraan pemerintah saat ini. Perbedaan kedua undang-undang tersebut salah satunya mengatur mengenai garis pantai yang digunakan sebagai acuan penarikan garis batas. Pada undang-undang yang lama, acuan penarikan garis batas berdasarkan air surut terendah (Low Water), sedangkan pada aturan perundang-undangan yang baru mengacu pada batas pasang air laut tertinggi (High Water) Dari perubahan kebijakan tersebut maka terjadi perbedaan garis dasar yang berdampak pada tata cara penarikan garis pantai dimana jarak antara dua garis tersebut dipengaruhi oleh selisih air terendah dengan tertinggi yang berdampak pada luas wilayah pengelolaan laut (Prayogi, 2016; Winarso dkk, 2010).

Penelitian mengenai perbedaan garis dasar pernah dilakukan oleh Tiarasani \& Sabri (2012). Penelitian tersebut melakukan perbandingan luas wilayah pengelolaan laut daerah provinsi dengan tiga peta dasar yang memiliki garis pantai yang berbeda-beda diantaranya Peta Lingkungan Pantai Indonesia (LPI), Peta Rupa Bumi Indonesia (RBI) Digital Kota Semarang-Kabupaten Kendal, Peta Laut Jawa - Pantura yang dibuat oleh Dinas Oseanografi dan Hidrografi TNI-AL. Hasil dari penelitian tersebut menunjukkan pemilihan garis dasar mempengaruhi bentuk garis batas dan batas klaim empat mil laut. Selain itu pemilihan garis dasar juga mempengaruhi bentuk dan titik batas di laut. Penelitian kedua dilakukan oleh Antunes (2000) dengan membandingkan kondisi morfologi yang berbeda (bertebing dan landai). Hasil penelitian tersebut menunjukkan bahwa penentuan garis dasar akan berpengaruh signifikan pada beberapa area khususnya di daerah landai dan tunggang pasut tinggi. Sebaliknya, tidak akan berpengaruh signifikan pada daerah yang bermorfologi tebing dan memiliki tunggang pasut rendah.

Penelitian ketiga dilakukan oleh Prayogi (2016) dengan menentukan batas pengelolaan laut (UU Nomor 32 Tahun 2004) dan batas bagi hasil kelautan (UU Nomor 23 Tahun 2014) antara Kota Surabaya, Kabupaten Sidoarjo, Bangkalan dan Sampang terkait keberadaan tanah Oloran. Dari hasil penelitian menunjukkan bahwa klaim kepemilikan tanah Oloran hanya berdampak pada batas pengelolaan laut antara Surabaya dan Sidoarjo dengan luas laut yang saling bertampalan sebesar 419 ha dan batas bagi hasil kelautan dengan luas laut yang saling bertampalan sebesar 2.258 ha. Penelitian keempat dilakukan oleh Ayuningtyas (2016) mengenai penentuan batas pengelolaan laut (UU Nomor 32 Tahun 2004) dan batas bagi hasil kelautan (UU Nomor 23 Tahun 2014) dilakukan di Kota Surabaya, Kabupaten Gresik dan Kabupaten Bangkalan terkait sengketa pulau Galang. Dari penelitian ini diperoleh hasil tarikan batas yang berbeda-beda akibat perubahan dari UU Nomor 32 Tahun 2004 menjadi UU Nomor 23 Tahun 2014 yaitu berubahnya garis pantai sebagai acuan penarikan batas wilayah laut. Dari penelitian tersebut menghasilkan Dana Bagi Hasil (DBH) kelautan Terminal Teluk Lamong, wilayah yang memperoleh bagi hasil hanya Kota Surabaya dan Kabupaten Gresik. Akibat dari perubahan UU, perubahan terkecil pada wilayah Teluk Lamong sebesar 11,291 ha jika Pulau Galang masuk Kabupaten Gresik.

Penelitian kelima dilakukan oleh Siregar dkk (2021) untuk mengetahui luas batas dan perbedaan batas wilayah laut di Provinsi Kepulauan Riau menggunakan metode kartometrik. Garis pangkal yang digunakan dalam penelitian tersebut adalah air surut terendah yang kemudian penarikan garis batas dilakukan overlay untuk mengetahui selisih antara kedua batas. Dari penelitian tersebut diketahui bahwa penarikan batas antara dua pulau berhadapan menggunakan metode median line sedangkan overlay dilakukan dengan citra Sentinel 1-A dengan batas Maritim Indonesia yang menghasilkan selisih luas sebesar $55,814 \mathrm{~km}^{2}$. Astuti dkk (2021) juga melakukan penelitian mengenai batas pengelolaan wilayah laut yang bertujuan untuk mengetahui teknis penegasan batas pada provinsi berciri kepulauan serta luas wilayah pengelolaan lautnya menggunakan metode kartometrik pada Peta RBI skala 1:50.000 dan pada Citra Sentinel-1A. Penarikan garis batas menggunakan tiga garis pangkal yaitu kepulauan, normal dan lurus. Hasil penelitian tersebut menunjukkan bahwa wilayah laut Provinsi Bangka Belitung lebih luas dibandingkan dengan wilayah darat dimana pada data Citra Sentinel-1A sebesar 67,6 \% sedangkan pada data Peta RBI sebesar $67,9 \%$.

Oleh karena itu, penelitian ini bertujuan untuk mengetahui pengaruh datum vertikal sebagai garis dasar 
dalam penegasan batas wilayah laut akibat perubahan UU Nomor 32 tahun 2004 dan UU Nomor 23 tahun 2014. Penelitian ini dibatasi dengan studi literatur dimana aspek yang diperhitungkan dari perubahan UU tersebut adalah Penegasan Garis Pangkal Nasional, Pendefinisian Pulau dan Luas Wilayah Daerah, Lokasi Sumber Daya Alam (SDA) dan DBH.

\section{Data dan Metodologi}

\subsection{Pasang Surut}

Pasang surut merupakan fenomena naik turunnya permukaan air laut yang disebabkan oleh gaya gravitasi antara bulan, bumi dan matahari yang terjadi secara periodik sehingga perolehan data pasang surut dapat diprediksi (Triatmojo, 1999). Pengaruh bulan 2,2 kali lebih besar dibandingkan gaya tarik matahari yang memiliki masa lebih besar dibandingkan massa bulan. Hal ini disebabkan karena bulan memiliki jarak yang lebih dekat dibandingkan dengan matahari (Triatmojo, 1999). Ongkosongo (1989) menyatakan bahwa pembentukan pasang surut air laut dipengaruhi oleh gerakan utama matahari dan bulan diantaranya (a) Revolusi bumi terhadap matahari dengan orbitnya berbentuk elips memiliki periode 365,25 hari, (b) Revolusi bulan terhadap bumi dengan orbitnya berbentuk elips memiliki periode 29,5 hari dan (c) Perputaran bumi terhadap sumbunya memiliki periode 24 jam. Gambar 1 merupakan gaya pembangkit pasang surut.

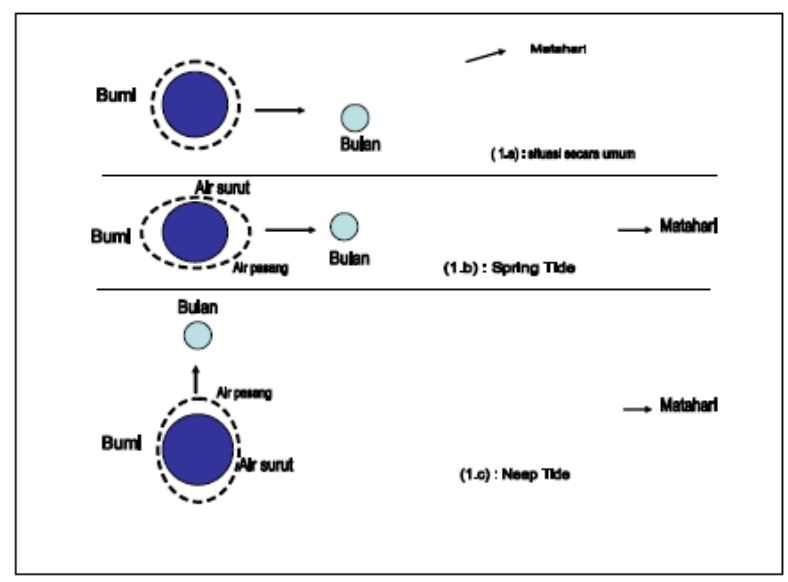

Gambar 1. Pembangkit Pasang Surut (Antunes, 2000)

Datum pasang surut merupakan datum vertikal yang diperoleh dari pengamatan pasang surut yang idealnya diamati selama 18,6 tahun. Hasil perhitungan ini kemudian digunakan untuk menentukan Chart Datum. Chart Datum merupakan referensi ketinggian yang digunakan untuk pembuatan peta laut maupun darat (Pariwono, 1989). Terdapat dua jenis Chart Datum, yaitu Low Water (LW) yang biasa digunakan sebagai referensi di laut dan High Water (HW) yang biasa digunakan sebagai referensi di darat. Dalam dokumen International Hydrographic Organization (IHO) dijelaskan bahwa Chart Datum merupakan bidang referensi acuan data kedalaman dan data Drying Height. Chart Datum memiliki variasi dari satu tempat ke tempat lain sehingga tidak sama.

\subsection{Datum Vertikal}

Ayuningtyas (2016); Gill \& Schultz (2001) menyatakan bahwa Datum Vertikal pada pengamat pasang surut adalah nilai ketinggian yang ditentukan dari hasil pengamatan dengan periode waktu tertentu. Datum vertikal merupakan referensi ketinggian yang disepakati dan digunakan untuk menentukan tinggi titik di pantai atau kedalaman titik di laut (Gambar 2). Datum ini terbagi menjadi tiga bagian yaitu High Water Level (Muka Air Tinggi), Mean Sea Level (Muka Air Rata-rata) dan Low Water Level (Muka Air Rendah).

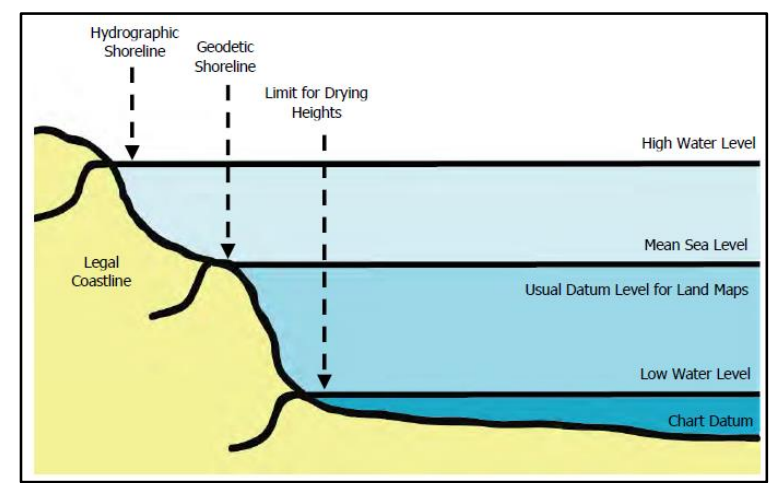

Gambar 2. Ilustrasi Datum Vertikal (Djunarsjah, 2011)

Gambar 2 diatas menunjukkan bahwa (a) High Water Level (HWL) adalah muka air tertinggi yang dicapai pada saat pasang dalam satu siklus pasang surut, (b) Mean Sea Level (MSL) adalah muka air rata-rata antara muka air tinggi rata-rata dan muka air rendah rata-rata dan (c) Low Water Level (LWL) adalah kedudukan air terendah yang dicapai pada saat surut dalam satu siklus pasang surut (Ayuningtyas, 2016). Ayuningtyas (2016); Poerbandono \& Djunarsjah (2005) menyatakan bahwa untuk keperluan pengukuran kedalaman (batimetri), acuan yang digunakan adalah muka air rendah sebagai garis pantai.

Indonesia yang merupakan negara kepulauan memiliki batas wilayah laut berdasarkan pada United Nations Convension on the Law of the Sea (UNCLOS) 1982 (Yusvitasari, 2020). Pada dokumen UNCLOS 1982 dijelaskan diantaranya (a) Kedudukan permukaan laut pada batas air rendah (Limit for Drying Height) dinyatakan pada garis air rendah (LWL/ chart datum), (b) Kedudukan permukaan laut pada garis pantai untuk pemetaan topografi (Geodetic Shore Line) pada bidang MSL dan (c) Kedudukan permukaan laut pada garis pantai yang digunakan untuk pemetaan hidrografi (Hydrographic Shore Line) berada di bidang HWL.

\subsection{Peta LPI Sebagai Peta Dasar}

Peta LPI merupakan gabungan peta RBI dan peta laut di wilayah pantai dalam satu proyeksi (Ayuningtyas, 2016). Peta ini merupakan representasi permukaan bumi secara grafis baik ke arah darat atau laut (Prayogi, 2016). Peta ini menampilkan beberapa informasi hidrografi yang tersedia 
dalam skala 1:50.000 dan 1:250.000. Peta ini digunakan sebagai peta dasar pembuatan peta tematik pada wilayah perairan pantai sebagai bentuk pengembangan infrastruktur data spasial baik tingkat daerah maupun nasional. Peta LPI yang disajikan dalam lembar peta dengan sistem proyeksi yang sama digunakan sebagai sumber informasi wilayah darat dan laut untuk memudahkan dalam perencanaan pembangunan nasional di wilayah pantai (Ayuningtyas, 2016; Prayogi, 2016).

\subsection{Teknis Delimitasi Batas Laut}

Pemerintah telah mengatur mengenai teknis delimitasi batas laut pada Peraturan Menteri Dalam Negeri (Permendagri) Nomor 141 Tahun 2017. Penetapan batas daerah di laut dilakukan secara kartometris dengan tahapan yaitu (a) Penyiapan dokumen, (b) Penentuan garis pantai, (c) Pengukuran dan penentuan batas dan (d) Pembuatan peta batas daerah di laut. Hasil dari proses delimitasi batas ditampilkan dalam peta batas kewenangan pengelolaan daerah wilayah laut berupa peta tematik. Peta tersebut menggambarkan letak titik koordinat batas berupa garis serta unsur-unsur peta dasar minimal satu segmen dengan koridor batas minimal $15 \mathrm{~cm}$ dari garis batas di atas peta. Penentuan garis pantai dilakukan dengan mengidentifikasi peta dasar secara kartometrik. Penggunaan garis pantai diperuntukkan untuk penentuan wilayah administrasi dalam pengelolaan lingkungan laut. Garis pantai yang dimaksud merupakan pertemuan antara daratan dengan lautan pada pasang tertinggi.

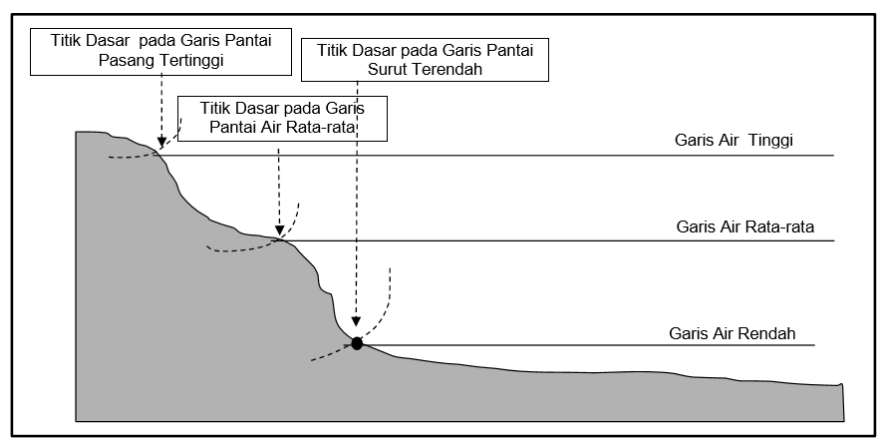

Gambar 3. Penarikan garis batas daerah di laut sejauh maksimum 12 mil laut dari garis pantai untuk provinsi (Permendagri Menteri Dalam Negeri No. 141 Tahun 2017)

Gambar 3 merupakan penarikan garis batas daerah di laut sejauh maksimum 12 mil laut dari garis pantai untuk provinsi. Penentuan titik dasar yaitu dengan melihat perpotongan garis pasang tertinggi untuk mengukur batas daerah laut yang ditarik 12 mil laut ke arah perairan kepulauan untuk provinsi. Dalam penentuan batas daerah di lingkungan laut terdapat tiga kondisi diantaranya (a) Pantai yang berhadapan dengan laut lepas (lebih dari 12 mil laut), (b) Pantai yang berhadapan dengan daerah lain dan (c) Pantai yang saling berdampingan dengan pantai daerah lain. Kondisi lain yang menjadi pengaruh dalam penentuan batas laut adalah posisi pulau $<12$ mil laut yang berada dalam satu provinsi.

\subsection{Metodologi Penelitian}

Metode yang digunakan dalam penelitian ini yaitu studi literatur pada dokumen diantaranya UU dan dokumen terkait. Analisis spasial dilakukan untuk mengetahui pengaruh kelerengan terhadap pergeseran garis dasar di lapangan dan di peta.

\section{Hasil dan Pembahasan}

\subsection{Pengaruh Datum Vertikal pada Penegasan Garis Pangkal Nasional}

Prinsip penarikan garis batas di laut telah mengadopsi hukum laut internasional UNCLOS dan kemudian teknisnya diatur dalam A Manual on Technical Aspec of UNCLOS 1982 (TALOS). Pasal 5 UNCLOS 1982 dijelaskan bahwa garis pangkal normal adalah LW dimana terdapat pemahaman yang berbeda-beda pada tiap negara. Hal ini menunjukkan bahwa belum ada keseragaman dalam penentuan garis air rendah. Oleh sebab itu, pada UNCLOS memberi kebebasan kepada tiap negara untuk menentukan titik dasar. Di Indonesia, di dalam UU Nomor 23 tahun 2014, titik dasar yang digunakan untuk penarikan batas dimulai pada perpotongan garis pasang tertinggi. Pada aturan yang lama yaitu UU Nomor 32 tahun 2004 titik dasar yang digunakan untuk penarikan batas dimulai pada perpotongan garis surut terendah.

Kondisi perbedaan garis pangkal normal yang terdapat dalam UU akan berdampak pada penarikan garis batas. Semakin rendah datum vertikal yang dipilih maka semakin terdorong lebih jauh ke laut yang akan mempengaruhi luas wilayah pengelolaan laut dimana juga dipengaruhi oleh kondisi morfologi pantai khususnya kelerengan. Klasifikasi lereng yang digunakan dalam penelitian ini ditunjukkan pada Tabel 1 .

\begin{tabular}{cc}
\multicolumn{2}{c}{ Tabel 1. Klasifikasi kemiringan lereng(Arsyad, 2009) } \\
\hline Kemiringan Lereng (\%) & Keterangan \\
\hline $0-3$ & Datar \\
$3-8$ & Landai \\
$8-15$ & Agak Miring \\
$15-30$ & Miring \\
$30-45$ & Agak Curam \\
$45-65$ & Curam \\
$>65$ & Sangat Curam \\
\hline
\end{tabular}

Kajian pengaruh perbedaan penggunaan garis surut terendah dengan pasang tertinggi dilakukan pada tujuh kondisi lereng yaitu 0 - $3 \%$ (datar), 3 - $8 \%$ (landai), 8 $15 \%$ (agak miring), 15 - $30 \%$ (miring), 30 - $45 \%$ (agak curam), $45-65 \%$ (curam) dan $>65 \%$ (sangat curam) pada nilai maksimum setiap kelas. Klasifikasi lereng mengacu pada klasifikasi menurut Arsyad (2009). Permendagri Nomor 141 Tahun 2017 secara spesifik tidak mengatur mengenai penggunaan skala dalam pembuatan peta batas di laut. Dalam Permendagri tersebut hanya dijelaskan bahwa pembuatan peta batas dalam format digital menggunakan peta dasar skala terbesar edisi terbaru yang tersedia, sedangkan untuk hasil peta batas dalam bentuk cetak (hard copy), skala minimal yang digunakan yaitu 
diantaranya (a) Batas Provinsi dengan skala $1: 500.000$, (b) Batas Kabupaten dengan skala $1: 100.000$ dan (c) Batas Kota dengan skala $1: 50.000$.

Pada penelitian ini, kajian pergeseran titik pangkal akibat perbedaan garis dasar (LW dan HW) dilakukan skenario yaitu bergeser sebesar 1, 3 dan 5 meter pada skala yang mengacu pada Permendagri Nomor 141 Tahun 2017 mengenai pembuatan peta batas dalam bentuk cetak. Hasil kajian selengkapnya seperti terlihat pada Tabel 2, Tabel 3 dan Tabel 4.

Tabel 2 Besar pergeseran titik pangkal pada skala peta 1: 50.000

\begin{tabular}{|c|c|c|c|c|c|c|}
\hline \multirow{2}{*}{$\begin{array}{l}\text { Kemiringan } \\
\text { Lereng }(\%)\end{array}$} & \multicolumn{2}{|c|}{$\begin{array}{l}\text { Pergeseran titik pangkal HW ke } \\
\text { LW (1 m) }\end{array}$} & \multicolumn{2}{|c|}{$\begin{array}{c}\text { Pergeseran titik pangkal HW ke } \\
\text { LW }(3 \mathrm{~m})\end{array}$} & \multicolumn{2}{|c|}{$\begin{array}{l}\text { Pergeseran titik pangkal HW ke LW } \\
\text { (5 m) }\end{array}$} \\
\hline & Di Lapangan (m) & $\begin{array}{l}\text { Di Peta } \\
(\mathrm{mm})\end{array}$ & Di Lapangan (m) & $\begin{array}{l}\text { Di Peta } \\
(\mathrm{mm})\end{array}$ & Di Lapangan (m) & $\begin{array}{c}\text { Di Peta } \\
\text { (mm) }\end{array}$ \\
\hline $0-3$ & 33.32 & 0.666 & 99.97 & 1.999 & 166.62 & 3.332 \\
\hline $3-8$ & 12.47 & 0.249 & 37.42 & 0.748 & 62.37 & 1.247 \\
\hline $8-15$ & 6.62 & 0.132 & 19.85 & 0.397 & 33.08 & 0.662 \\
\hline $15-30$ & 3.23 & 0.065 & 9.70 & 0.194 & 16.16 & 0.323 \\
\hline $30-45$ & 2.07 & 0.041 & 6.21 & 0.124 & 10.35 & 0.207 \\
\hline $45-65$ & 1.32 & 0.026 & 3.95 & 0.079 & 6.58 & 0.132 \\
\hline$>65$ & 1.07 & 0.021 & 3.22 & 0.064 & 5.37 & 0.107 \\
\hline
\end{tabular}

Tabel 3 Besar pergeseran titik pangkal pada skala peta 1: 100.000

\begin{tabular}{|c|c|c|c|c|c|c|}
\hline \multirow{2}{*}{$\begin{array}{l}\text { Kemiringan } \\
\text { Lereng (\%) }\end{array}$} & \multicolumn{2}{|c|}{$\begin{array}{c}\text { Pergeseran titik pangkal HW } \\
\text { ke LW (1 m) }\end{array}$} & \multicolumn{2}{|c|}{$\begin{array}{c}\text { Pergeseran titik pangkal HW ke } \\
\text { LW (3 m) }\end{array}$} & \multicolumn{2}{|c|}{$\begin{array}{c}\text { Pergeseran titik pangkal HW ke } \\
\text { LW (5 m) }\end{array}$} \\
\hline & Di Lapangan (m) & $\begin{array}{l}\text { Di Peta } \\
\text { (mm) }\end{array}$ & Di Lapangan (m) & $\begin{array}{l}\text { Di Peta } \\
\text { (mm) }\end{array}$ & Di Lapangan (m) & $\begin{array}{l}\text { Di Peta } \\
\text { (mm) }\end{array}$ \\
\hline $0-3$ & 33.32 & 0.333 & 99.97 & 1.000 & 166.62 & 1.666 \\
\hline $3-8$ & 12.47 & 0.125 & 37.42 & 0.374 & 62.37 & 0.624 \\
\hline $8-15$ & 6.62 & 0.066 & 19.85 & 0.198 & 33.08 & 0.331 \\
\hline $15-30$ & 3.23 & 0.032 & 9.70 & 0.097 & 16.16 & 0.162 \\
\hline $30-45$ & 2.07 & 0.021 & 6.21 & 0.062 & 10.35 & 0.104 \\
\hline $45-65$ & 1.32 & 0.013 & 3.95 & 0.039 & 6.58 & 0.066 \\
\hline$>65$ & 1.07 & 0.011 & 3.22 & 0.032 & 5.37 & 0.054 \\
\hline
\end{tabular}

Tabel 4 Besar pergeseran titik pangkal pada skala peta 1: 500.000

\begin{tabular}{|c|c|c|c|c|c|c|}
\hline \multirow{2}{*}{$\begin{array}{l}\text { Kemiringan } \\
\text { Lereng (\%) }\end{array}$} & \multicolumn{2}{|c|}{$\begin{array}{l}\text { Pergeseran titik pangkal HW ke } \\
\text { LW (1 m) }\end{array}$} & \multicolumn{2}{|c|}{$\begin{array}{c}\text { Pergeseran titik pangkal HW ke } \\
\text { LW ( } 3 \mathrm{~m})\end{array}$} & \multicolumn{2}{|c|}{$\begin{array}{l}\text { Pergeseran titik pangkal HW ke } \\
\text { LW }(5 \mathrm{~m})\end{array}$} \\
\hline & Di Lapangan (m) & $\begin{array}{l}\text { Di Peta } \\
\text { (mm) }\end{array}$ & Di Lapangan (m) & $\begin{array}{l}\text { Di Peta } \\
\text { (mm) }\end{array}$ & Di Lapangan (m) & $\begin{array}{c}\text { Di Peta } \\
\text { (mm) }\end{array}$ \\
\hline $0-3$ & 33.32 & 0.067 & 99.97 & 0.200 & 166.62 & 0.333 \\
\hline $3-8$ & 12.47 & 0.025 & 37.42 & 0.075 & 62.37 & 0.125 \\
\hline $8-15$ & 6.62 & 0.013 & 19.85 & 0.040 & 33.08 & 0.066 \\
\hline $15-30$ & 3.23 & 0.006 & 9.70 & 0.019 & 16.16 & 0.032 \\
\hline $30-45$ & 2.07 & 0.004 & 6.21 & 0.012 & 10.35 & 0.021 \\
\hline $45-65$ & 1.32 & 0.003 & 3.95 & 0.008 & 6.58 & 0.013 \\
\hline$>65$ & 1.07 & 0.002 & 3.22 & 0.006 & 5.37 & 0.011 \\
\hline
\end{tabular}


Pergeseran-pergeseran yang terjadi hampir tidak terlihat atau bisa dikatakan tidak signifikan untuk dasar mengukur limit batas maritim. Gambar 4 merupakan

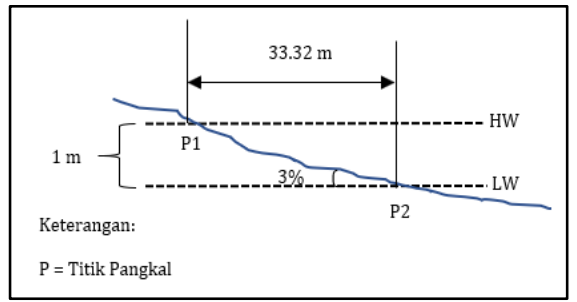

(a)

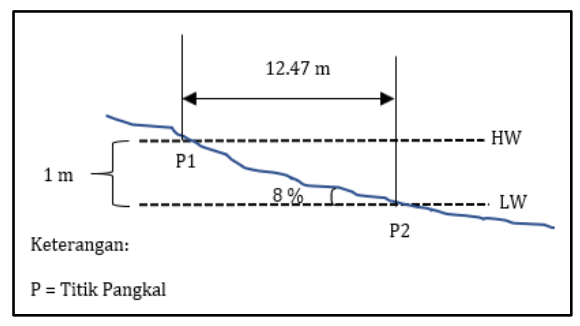

(d)

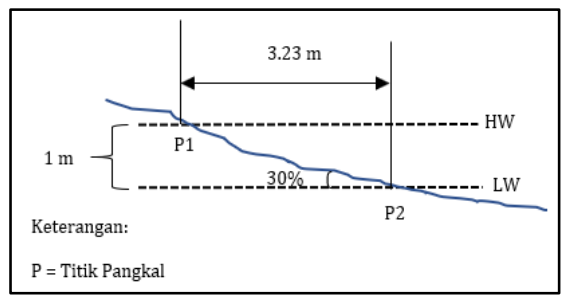

(g)

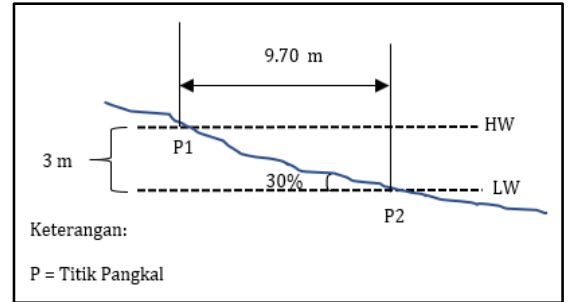

(b)

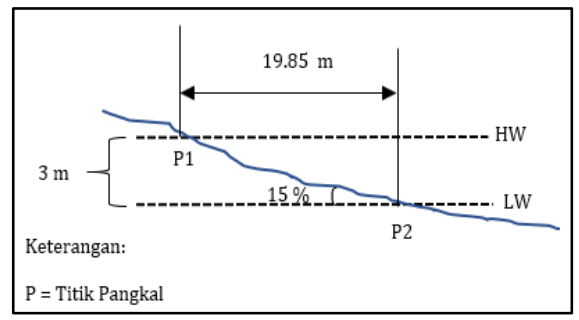

(e)

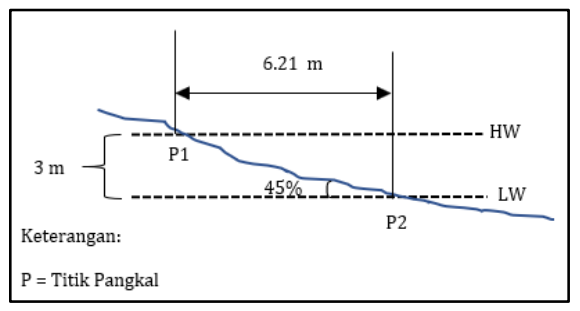

(h) sampling ilustrasi grafis yang telah dilakukan pada tiga skala peta $(1: 50.000,1: 100.000$ dan 1:500.000) dengan berbagai tingkat klasifikasi kelerengan.

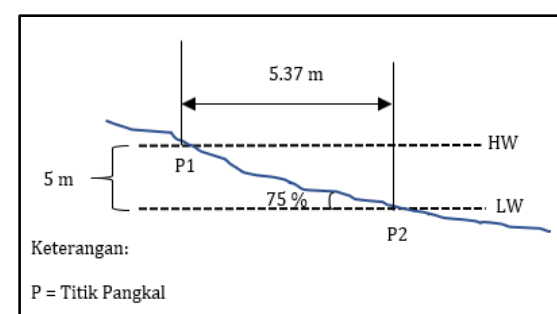

(c)

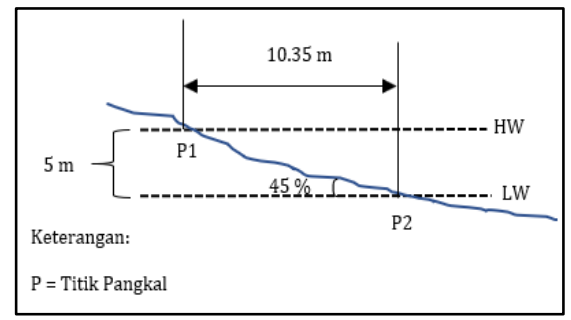

(f)

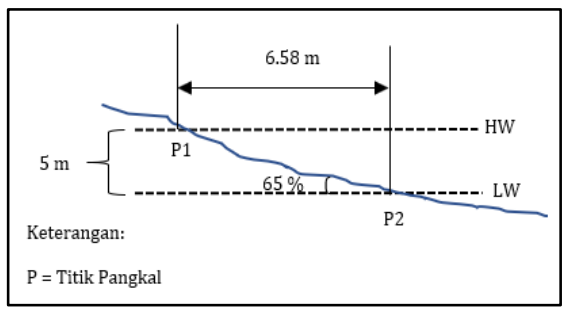

(i)

Gambar 4. Pergeseran titik pangkal akibat perbedaan LW ke HW di lapangan. (a) Perbedaan LW dan HW sebesar 1 m dengan lereng 3\%, (b) Perbedaan LW dan HW sebesar 3 m dengan lereng 30\%, (c) Perbedaan LW dan HW sebesar 5 m dengan lereng 75\%, (d) Perbedaan LW dan HW sebesar 1 m dengan lereng 8\%, (e) Perbedaan LW dan HW sebesar 3 m dengan lereng $15 \%$, (f) Perbedaan LW dan HW sebesar 5 m dengan lereng 45\%, (g) Perbedaan LW dan HW sebesar 1 m dengan lereng 30\%, (h) Perbedaan LW dan HW sebesar 3 m dengan lereng 45\% dan (i) Perbedaan LW dan HW sebesar $5 \mathrm{~m}$ dengan lereng $65 \%$

\subsection{Pengaruh Datum Vertikal pada Pendefinisian Pulau}

Pada dokumen UNCLOS dijelaskan bahwa pulau merupakan suatu daratan dimana pada saat perairan pasang tertinggi, daratan tersebut masih terlihat dan tidak tergenang air. Penetapan HW akan berdampak pada penentuan pulau dan batas maritim (Antunes, 2000). Suatu pulau memiliki arti penting dalam penentuan limit batas wilayah laut. Peranan informasi pasang surut yang kaitannya dengan HW dalam pendefinisian pulau menjadi penting karena dapat menentukan suatu daratan termasuk pulau atau tidak (Joyosumarto, 2013). Perubahan UU Nomor 32 Tahun 2004 menjadi UU Nomor 23 Tahun 2014 mengakibatkan berubahnya datum vertikal sebagai garis dasar dalam penegasan batas wilayah laut yaitu LW ke HW.
Joyosumarto (2013) menyatakan bahwa dampak dari perbedaan penggunaan datum vertikal adalah semakin rendah garis dasar maka semakin sempit wilayah pengelolaan laut. Sebaliknya, semakin tinggi garis dasar maka semakin luas wilayah pengelolaan laut. Gambar 5 dibawah dijelaskan bahwa jika MHW dijadikan sebagai air pasang tertinggi, maka fitur daratan dianggap sebagai pulau. Sebaliknya jika Highest Astronomical Tide (HAT) dijadikan sebagai air pasang, maka fitur daratan dianggap sebagai Low-Tide Elevation (LTE) (Antunes, 2000). Elevasi pasang surut hanya bisa menghasilkan ruang maritim jika terletak dalam laut teritorial (Antunes, 2000). 


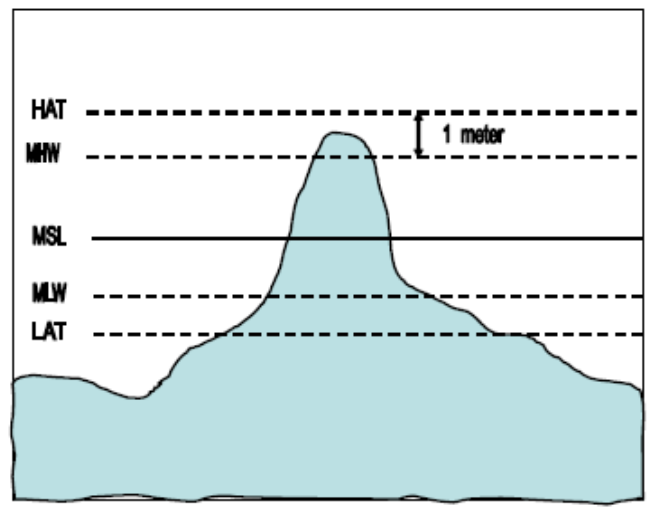

Gambar 5. Pulau dan datum vertikal (Antunes, 2000)

\subsection{Pengaruh Datum Vertikal pada Luas Wilayah Daerah} dan DBH

Batas laut daerah adalah pemisah antara daerah yang berbatasan berupa garis khayal (imajiner) di laut dan daftar koordinat di peta yang dalam implementasinya merupakan batas kewenangan pengelolaan sumberdaya di wilayah laut (Joyosumarto, 2013). Batas kewenangan daerah di laut, memiliki arti penting bagi kabupaten/ kota dan pemerintah provinsi. Batas daerah yang tidak jelas dapat memicu konflik di wilayah perbatasan dan menghambat penyelenggaraan fungsi pemerintahan daerah. Penentuan dan penegasan batas merupakan agenda penting dalam melaksanakan otonomi daerah. Dengan diraihnya otonomi daerah, maka Pemerintah Daerah menerima Dana Alokasi Umum (DAU) dan Dana Alokasi Khusus (DAK). Untuk menerima DAU, salah satu indikatornya adalah dengan melihat luas wilayah suatu daerah. Untuk itu, maka luas wilayah suatu daerah menjadi sangat penting untuk diketahui berdasarkan batas-batas daerah yang jelas. Berdasarkan UU Nomor 23 Tahun 2014 dijelaskan bahwa kewenangan pengelolaan wilayah laut daerah kabupaten/ kota untuk perhitungan DBH kelautan sejauh 4 mil laut yang diukur dari garis pantai ke arah laut serta 12 mil laut untuk pemerintah provinsi. Garis pantai yang digunakan sebagai acuan penarikan garis batas adalah batas pasang air laut tertinggi. Pemilihan titik dan garis dasar akan berdampak pada luas pengelolaan wilayah laut.

\section{Kesimpulan}

Dari hasil penelitian dapat disimpulkan bahwa penentuan garis dasar LW dan HW akan mempengaruhi luas pengelolaan wilayah laut, garis dasar dan titik dasar. Semakin rendah garis dasar maka semakin sempit wilayah pengelolaan laut. Sebaliknya, semakin tinggi garis dasar maka semakin luas wilayah pengelolaan laut. Letak garis dasar LW dan HW akan berdampak pada lokasi SDA khususnya pada wilayah yang berdampingan dekat dengan wilayah lain. Luas wilayah mempengaruhi besaran DBH pada suatu wilayah yang ditentukan dari garis dasar.

\section{Pernyataan Konflik Kepentingan}

Penulis menyatakan tidak ada konflik kepentingan dalam artikel ini (The authors declare no competing interest).

\section{Referensi}

Abidin, H. Z. (2001). Beberapa Pemikiran Tentang Penetapan dan Penegasan Batas di Laut. GeoInformatika Jurnal, 2.

Adikara, A. P. B., \& Munandar, A. I. (2021). Tantangan Kebijakan Diplomasi Pertahanan Maritim Indonesia Dalam Penyelesaian Konflik Laut Natuna Utara. Jurnal Studi Diplomasi Dan Keamanan, 13(1).

Antunes, N. S. M. (2000). The Importance of the tidal datum in the definition of maritime limits and boundaries. Ibru.

Arddinatarta, M., Sudarsono, B., \& Awaluddin, M. (2016). Analisis Dampak Perubahan Garis Pantai Terhadap Batas Pengelolaan Wilayah Laut Kabupaten Jepara. Jurnal Geodesi Undip, 5(3), 52-60.

Arsyad, S. (2009). Konservasi tanah dan air. PT Penerbit IPB Press.

Astuti, E. D. T., Sabri, L. M., \& Awwaluddin, M. (2021). Analisis Penentuan Batas Pengelolaan Wilayah Laut Provinsi Berciri Kepulauan dari Citra Sentinel-1a (Studi Kasus: Provinsi Kep. Bangka Belitung). Jurnal Geodesi Undip, 10(2), 69-77.

Ayuningtyas, M. (2016). Analisa Pengaruh Perubahan Undangundang Nomor 32 Tahun 2004 Menjadi Undang-Undang Nomor 23 Tahun 2014 Terhadap Batas Wilayah Laut Daerah (Studi Kasus: Kota Surabaya, Kabupaten Gresik Dan Kabupaten Bangkalan) (pp. 1-116). Skripsi. Institut Teknologi Sepuluh Nopember Surabaya.

Djunarsjah. (2011). Riset Garis Pantai Bakosurtanal. Bandung: KK Sains dan Rekayasa.

Gill, S. K., \& Schultz, J. R. (2001). Tidal datums and their applications.

Joyosumarto, S. (2013). Pengaruh Datum Vertikal (Tidal Datum) dalam Delimitasi Batas Maritim (pp. 1-23). Jurusan Teknik Geodesi Fakultas Teknik. Universitas Gadjah Mada. Yogyakarta.

Kapahese, I. V. M. (2021). Tinjauan Tentang Penyelesaian Sengketa Batas Wilayah Antar Negara Menurut Perspektif Hukum Internasional. Lex Administratum, 9(3).

Karlina, W. R., \& Viana, A. S. (2020). Pengaruh Naiknya Permukaan Air Laut terhadap Perubahan Garis Pangkal Pantai Akibat Perubahan Iklim. Jurnal Komunikasi Hukum (JKH), 6(2), 757-586.

Lamionda, D. R. P. (2020). Analisis Yuridis Pengaturan Batas Laut Wilayah Antara Indonesia (Batam) dan Singapura Menurut Undang-Undang Nomor 43 Tahun 2008 Tentang Wilayah Negara. Lex Et Societatis, 8(1).

Ongkosongo. (1989). Pasang Surut (Pusat Penelitian dan Pengembangan Oseanologi (ed.)). Lembaga Ilmu Pengetahuan Indonesia.

Pariwono. (1989). Gaya Penggerak Pasang Surut (P. O. dan 
Suyarso (ed.)). Puslitbang Oseanologi LIPI.

Peraturan Menteri Dalam Negeri Nomor 76 Tahun 2012 Tentang Pedoman Penegasan Batas Daerah.

Peraturan Menteri Dalam Negeri Nomor 141 Tahun 2017 Tentang Penegasan Batas Daerah.

Poerbandono, D. E., \& Djunarsjah, E. (2005). Survei hidrografi. Refika Aditama. Bandung, 166.

Prayogi, S. (2016). Analisa Penetapan Batas Pengelolaan Laut Dan Bagi Hasil Kelautan Antara Kota Surabaya, Kabupaten Sidoarjo, Bangkalan Dan Sampang (pp. 187). Skripsi. Institut Teknologi Sepuluh Nopember Surabaya.

Siregar, P. N., Sudarsono, B., \& Sabri, L. M. (2020). Analisis Hubungan Batas Pengelolaan Wilayah Laut Provinsi Kepulauan Riau dengan Batas Maritim Negara Indonesia Menggunakan Citra Sentinel-1A. Jurnal Geodesi Undip, 10(1), 95-104.

Tiarasani, A., \& Sabri, L. M. (2012). Analisis Alternatif Batas Wilayah Laut Kota Semarang Dan Kabupaten Kendal.
Jurnal Geodesi Undip, 1(1), 1-10.

Triatmojo, B. (1999). Teknik Pantai. Fakultas Teknik, Universitas Gadjah Mada. $397 \mathrm{hlm}$.

Undang-Undang Nomor 32 Tahun 2004. Tentang Pemerintahan Daerah.

Undang-Undang Nomor 23 Tahun 2014. Tentang Pemerintahan Daerah.

United Nations Convension on the Law of the Sea (UNCLOS) 1982.

Winarso, G., Joko, H., \& Arifin, S. (2010). Kajian penggunaan data inderaja untuk pemetaan garis pantai (studi kasus Pantai Utara Jakarta). Jurnal Penginderaan Jauh Dan Pengolahan Data Citra Digital, 6.

Yusvitasari, D. (2020). Strategi Pemerintah Indonesia dalam Penyelesaian Sengketa Tentang Penetapan Batas Laut Antara Indonesia dan Malaysia di Blok Ambalat. Jurnal Pendidikan Kewarganegaraan Undiksha, 8(1), 47-60. 